\title{
Democracy will never be the same again: 21st Century Protest and the Transformation of Politics
}

\author{
La democracia nunca volverá a ser igual: Las protestas \\ del siglo XXI y la transformación de la política
}

SIMON TORMEY

The University of Sydney (Australia)

Artículo recibido: 5 noviembre 2014

Solicitud de revisión: 30 diciembre 2014

Artículo aceptado: 14 abril 2015

\begin{abstract}
This paper looks at the current wave of protests and demonstrations and asks whether what we are witnessing is the emergence of a new movement against austerity and in favour of democracy, as many suggest. The wider context is the crisis of representative politics, which is in turn transforming the nature of mobilisation, contestation and politics more generally. In place of traditional organisational structures, we are seeing the emergence of cloud, swarm and connective initiatives with characteristics that challenge and supplant traditional organisational politics. We are seeing the emergence of a politics that is resistant to 'politicians' of whatever ideology, seeking to recuperate power and agency from representatives. This creates an interesting tension at the heart of democracy: whether and to what extent democracy needs to 'reboot' or whether new political parties and movements can ally the connective to representational styles of politics to provide a way in which democracy can evolve.
\end{abstract}

Keywords: democracy, protest, representation, activism

Resumen

Este artículo examina la ola de protestas y manifestaciones, preguntándonos si, como muchos sugieren, lo que estamos presenciando es el surgimiento de un nuevo movimiento contra la austeridad y a favor de la democracia. El contexto político está marcado por una generalizada crisis de la política representativa, hecho que a su vez marca la transformación de la naturaleza de la movilización, de la contestación y de la política en general. Estamos presenciando el surgimiento de iniciativas con características cloud, swarm y conectivas que desafían y suplantan a las estructuras organizativas tradicionales. En la actualidad está emergiendo una forma de política que es resistente a los "políticos" de cualquier tipo de ideología y que trata de recuperar el poder de los representantes. Esto crea una tensión interesante en el corazón de la democracia: si, y en qué medida, la democracia necesita 'resetearse' o si los nuevos partidos y los nuevos movimientos políticos pueden aliar lo conectivo a estilos de 
representación política capaces de proporcionar una manera en la que la democracia pueda evolucionar.

Palabras clave: democracia, protestas, representación, activismo

\section{INTRODUCTION}

Since 2011 and the extraordinary events of the Arab Spring we have, it seems, entered a new phase of protest, revolt and rebellion (Castells, 2012; Mason, 2013). There will be debates about the degree to which the date itself is significant in terms of providing a marker for developments that have their origin in deep-lying phenomena. However, there seems to be a degree of consensus amongst interested commentators that the events around the Arab Spring resonated with sufficient force to provoke a ripple effect in terms of sparking rebellions, protests and insurrections across the world. The symbolic occupation of space associated with Tahrir Square quickly became emblematic of a kind of citizen activism then witnessed in Spain, in Occupy Wall Street, in the Pots and Pans Protests in Iceland, and more recently in public occupations and protests in Turkey, Bulgaria,Thailand, Brazil, Hong Kong and many other locations besides.

It is one thing to note outbursts of citizen disaffection, but what are the longer-term ramifications of such actions for democracy? To what degree are these otherwise separate events tied together in 'a movement'? Are today actions a movement against austerity? Or are they to be read as a movement in favour of democracy? Or are they just the latest manifestation of citizens' disapproval of what elites do in their name? A movement implies some sort of coalescence of ends and objectives. It implies a sharing of perspective. It also implies some singularity as far as organisation is concerned. A movement implies some minimal unity, either of purpose or affect or goal. How then might we think about this current phase as a movement? What would be its common features? And assuming that we can describe these protests on such terms, what are the implications for politics generally and democracy in particular? Where is this 'movement' - if such it be - taking us?

\section{THE PATTERN OF REVOLT}

Let's consider, firstly, some of the obvious ways in which these events are linked. Several points seem to suggest themselves: 
1. Object:A revolt against 'politicians' - the aspects of these protests that stands out is the contempt, anger and hatred expressed towards representatives or politicians (Mason, 2013). The Arab Spring had its origins in deep disaffection and mistrust of local elites across North Africa, culminating in the overthrow of the Egyptian Prime Minister. The accusation was that elites had become corrupt and indifferent to the needs of ordinary people. This in turn led to street protests and occupations as the logical as well as symbolic expression of people's outrage. With 'nowhere else to go', the street and squares become the setting for the expression of these frustrations. This gesture resonated in Spain, which has similarly endured a crisis of legitimacy brought about by corruption, cronyism and clientelism exercised by the two main political parties. Events in Iceland were sparked by evidence of collusion between politicians and bankers that led to the Icelandic state going bankrupt, and with it losing the savings and pensions of many citizens. Occupy Wall Street was a response to the incompetence and self-serving of 'the 1\%' or elites considered in general terms to include both bankers and politicians. In Turkey the protests were triggered by the insensitivity of local politicians to objections to an inappropriate development at Taksim Square. Around the world, politicians are in the firing line - as signalled not just by revolt but by the rise of populist movements dedicated to overturning 'bureaucracy', 'waste', and the corruption of elites.

2. Context:A revolt against austerity - the global financial crisis of 2008 unleashed unprecedented cutbacks in public spending across both the developed and developing world. It was ordinary people who paid for the incompetence of politicians and the quasi-criminal activities of bankers who gambled with the deposits and livelihoods of their own often unsuspecting clients and then went running to the taxpayer as their institutions went bust. With public finances in trouble so measures have been imposed to cut back on welfare, public services, education and benefits to the detriment of the very poorest elements of society. The focus of much public activity in Spain for example has been to roll back these measures. Groups such as La Plataforma de Afectados por las Hipotecas (РАH) have sprung up to defend mortgagees against the actions of banks seeking to repossess properties (Feenstra and Keane, 2014). In Greece an extensive network of direct action groupings, citizens solidarity initiatives, protests and demonstrations has characterised civil society over the past decade. Across Eu- 
rope citizens have protested and revolted against the harsh measures imposed by governments.

3. Capacity: New weapons of the weak - one of the most commentatedupon aspects of the current phase of revolt is the role played by ICT and social media technologies (Christensen, 2011; Morozov, 2012; Hill, 2013). There's a high degree of consensus that Twitter and Facebook amongst other technologies were an important factor in the spread of protests across the Arab speaking world in 2011. The evidence is even clearer in Spain where the initial event that precipitated the current unrest, the occupation of squares on 15 May 2011, was created through hashtags and callouts involving minimal organisation by existing groups or political parties (Anduiza et al., 2013; Postill, 2013; Toret, 2013). Occupy was a phenomenon that owed its extensive take up across the world to ІСт. What is becoming clearer is the degree to which these technologies facilitate mobilisation and organisation without the need for the infrastructure previously regarded as essential to the successful development of initiatives: leadership structures, funding, officials and so forth. Sometimes it just takes a suggestive hashtag or photo capturing the particular mood or anger of citizens can resonate and create the basis for a significant mobilisation. Whether it provides the basis for something more substantial is perhaps one of the most hotly-debated topics in social movement literatures; but it is clear that ICT is changing the nature and potential of organisational politics in a dramatic way.

For our purposes, it is important to bear in mind the particular kind of politics that ICT or Twitter-led mobilisation provokes because this will give us an insight into the particular kind of 'movement' that we are describing. Assuming that it makes sense to speak about these initiatives as being part of a movement, then it is worth thinking further about the characteristics they display. We can summarise them in terms of their being:

- Acepbelous - or 'leaderless'. The particular aspect that unites developments since 2011 is that they were triggered by ordinary citizens or activists who remained largely anonymous as events unfolded. Whilst it might be possible to identify certain activists, factions or groupings who initiate an event such as $15 \mathrm{M}$, it is the event itself that becomes the focus rather than the people who initiated it. The events took on a life of their own and gave rise to a largely spontaneous form of poli- 
tics focused on occupation, the creation of assemblies and other kinds of deliberative structures. The Arab Spring, through the events in Spain to Occupy were largely movements from below unaided and unassisted by existing organisations or leaders. This contrasts with more traditional political initiatives usually characterised by an identifiable leadership group. Political organisations have usually succeeded on the ability of the leadership to articulate demands that then attract a following to it. Event based and episodic revolts do not display classic movement characteristics as this has usually been thought about: appointed leaders, a clear division of labour, a 'head' and a 'body' in a relatively fixed formation.

- Non-programmatic - What also unites these actions is that they have their origin in an immediate reaction to a particular political and economic context rather than being a product of planning or organisation in the name of a particular ideology or programme. But of equal significance is the degree to which once created the occupations and assemblies resisted the call to develop a programme, demands, a manifesto. This has been an immense frustration to high profile leftists such as Slavoj Zizek,Alain Badiou and Jodi Dean who would like to see these movements develop a set of demands around which opinion could coalesce and which could then form the basis for a strategy to contest power - a 'counter-hegemonic bloc', to deploy Gramsci. But what seems to be the case is that the participants in these events rightly or wrongly associated such an approach with an exclusionary form or style of politics. This resistance to the development of a programme has not in this sense been haphazard or accidental. It has been the result of collective deliberation amongst participants. The view of participants at events such as $15 \mathrm{M}$ and Occupy has been that the development of demands or a programme would quickly lead to the development of a conventional political organisation or party which would enthuse and mobilise some, but not all. The participants clearly wished to avoid such an outcome, and in turn avoid gestures that split the initiative into as it were believers and non-believers, leaders and led. In this sense they enact a kind of anti-politics associated with the perspectives of those such as Subcomandante Marcos and John Holloway who see the function of insurgent initiatives such as these as creating political possibility, not an end project or blueprint (Marcos, 2001; Holloway, 2002). 
- Non/anti-representative - In light of the above, this is a movement that at one level resists representation or the apparatus of representative politics as that has long been thought about. None of these initiatives or events have so far given rise to a traditional movement or political party. Some of them have come and gone leaving little in the way of permanent memorial. In Spain for example, what we observe is some of those identifying with $15 \mathrm{M}$ creating political organisations, but of a new kind. Some of them such as Podemos and Party $\mathrm{X}$ reject the traditional hierarchy of political parties with clear leaderships and a standing bureaucracy in favour of the use of electronic Peer-2-Peer and Twiki technologies facilitating an interchange between activists. Other parties style themselves as protest parties, seeing their role exclusively in terms of humiliating the political class or making the case for a 'second transition' to a more democratic and proportional system of elections. None of these new political parties represent the Indignados as such. As is often stated by the parties themselves, the Indignados cannot be represented without losing what Indignados means: the description of all those who are angry or 'pissed off'. The parties are better characterised as an extension of protest, an extension of 'the street', or what is more the same, new tools for developing weapons in the struggle against elites. They are seeking to keep alive the spirit of direct and immediate participation by anyone who shares the conviction that the present misery needs to be resisted. That they take the form of political parties is more testament to the ease with which it is possible to create parties that are flatter, less hierarchical, or less like traditional parties in structure. The point should be clear: in Spain and elsewhere citizens are seeking ways of protesting, resisting, that evade the exclusionary character of politics as this has been practised hitherto (Feenstra, 2015). They seek open, participatory and deliberative mechanisms whether physical or virtual in which ordinary people can recuperate some sense of voice and value rather than being spoken for by others.

So any talk of the current phase of protest as tantamount to the emergence of a new movement has to be made with caution. None or very few of the characteristics that we associate with social and political movements would seem to be present in anything other than a rather superficial sense. Indeed we might go further: these are protests and revolts that display a unity only in relation to the unwillingness of participants to develop 
party or movement characteristics. They self-consciously avoid leadership, clear demands, manifestos, bureaucracy, offices, external funding. This gives witness to the emergence of a politics that is anti-and non-representative. Before asking ourselves where all this might be heading and what it means for democracy, it is I think useful to link these developments to a consideration of the wider political context in which they are taking place: the crisis of representative politics (Tormey, 2015).

\section{REPRESENTATION - WHAT'S HAPPENING?}

The preoccupation of today's activists with avoiding representative practices looks curious until we set in the context of what is happening elsewhere in mainstream as well as street politics. Considering the former it is difficult to avoid concluding that we are dealing with a much more generalised phenomenon that penetrates the nature of politics more generally. Consider the following four variables:

- The decline of participation in elections - Across the 'advanced democracies' we are witnessing a marked decline in engagement in electoral politics (Dalton, 2004; Hay, 2007). The long-term trend since the 1960s suggests that only presidential elections and general elections in parliamentary systems - show signs of staving-off decline. Yet even here the $60 \%$ turnout achieved by for example us presidential elections illustrates the problem starkly. $40 \%$ of electors cannot or will not engage in a process that takes a matter of minutes of their time. In Europe the long-term trend is also clear: fewer citizens are voting with the exception of moments of crisis when they perceive that there is something important at stake, as for example in Italy in 2013. Take 'crisis' away, and citizens are becoming increasingly inclined to ignore the spectacle. Elections at the supranational and subnational levels show the nature of the problem in even greater relief. The recent European elections attracted around 30\% of citizens in European countries or one citizen in three. And it was populist, protest and 'anti-political' parties who made the furthest advances. This of course is itself a symptom of a failing system, not a source of hope or salvation for representative politics (Alonso, 2014).

- The decline in membership of traditional political parties - Recent data from Europe shows the precipitous decline of membership in 
political parties over the past half-century (Mair and Van Biezen, 2001; Van Biezen et al., 2012). Where once the major political parties were able to attract between $30 \%$ of the voting population, now that figure is often below $10 \%$, and in some cases such as the un heading for 1 or $2 \%$. Given that political parties play a crucial transmission role between citizens and representatives, this is bad news for those who regard liberal democracy as the best means achieved so far to ensure that representation engages citizens directly and immediately in their daily lives and not just during periods of elections. However, citizens are turning their backs on traditional political parties - particularly traditional left parties such as PSOE, PSOK, Labour, and the SPD - and by extension on the means by which they used to be able to have some say in the political process. The result is that parties increasingly turn to business in order to find the means of keeping themselves going. It also means that they become progressively less sensitive to the needs of their own memberships, in turn reinforcing the impression that the leadership of political parties cares little for ordinary party activists. Politicians are becoming 'executive' style figures, competing with each other on the basis of their ability to speak directly to electors via the media. 'Style over substance' has become the watchword for today's politics.

- The decline of trust in politicians - Where once politicians were regarded as public servants, now they are regarded as figures who serve narrow sectional interests not the public interest. A recent nationwide survey in Australia shows the depth of the problem (Goot, 2002; Markus, 2013). Only $4 \%$ of those who were asked to respond to the question 'do you trust the politicians?' responded without equivocation. The majority answered negatively. Similarly, when citizens were asked to rank professions in the order to which they could be trusted, the response was that politicians ranked lowest of all and behind the usual scapegoats such as lawyers, real-estate agents and second-hand car salesman. As already noted, the stock of today's crop of politicians has never been lower - as reconfirmed through multiple iterations of longitudinal survey data such as Eurobarometer, the World Values Survey as well as discrete country studies such as that referred to above. The data is not uniform, in that there are areas of the world that show slower declines than others (as in Denmark for example); but overall the impression statistically and discursively is increasingly to query the integrity of and need for politicians. Indeed, the very term 'politi- 
cian' has become a byword for sleaze, corruption and self-interest. It is no surprise then that today's movements seek to distance themselves from the inheritance of 'the politician'. Where leadership figures do emerge, they display very different virtues to those associated with traditional politicians. For example in Spain the popularity of Ada Colau and Sister Teresa Forcades can be traced in good measure to their distance from the traditional figure of the politicians. Both are 'antipolitical' figures. Colau is a street activist working with РAH to highlight the iniquities enjoyed by ordinary people faced with repossession of their home. Forcades is a nun who by nature of her professional commitment disavowed the trappings of power to defend the poor and needy. It would be difficult to imagine figures who are less like today's politicians and elites.

- Interest in and knowledge of mainstream politics - Notwithstanding the fact that we live in highly politicised times, the decline of interest in 'high politics', that is the politics of our elected representatives had never been so marked (Flinders, 2012). Where once serious newspapers carried many pages of commentary on parliamentary and presidential proceedings, now the focus on 'infotainment'. TV and radio programmes devoted to scrutinising and examining politics that once occupied a prime-time position, are relegated to 'the graveyard slot', code for late-nights, early Sunday mornings - or they have been moved to obscure and little watched TV channels (A-PAC, The Parliamentary Channel, and so on). Amongst even the most politically literate part of the population the activities of our representatives attracts contempt rather than interest. By contrast, some of the great success stories in terms of mobilising young people have been online initiatives such as Avaaz.org and GetUp.org (Vromen, 2003). The common denominator in initiatives such as these is that they focus on particular issues which then become the subject of an extensive online campaign. They do so without representatives and representation, instead trading on crowd power: the ability of large numbers of people acting together to generate a response from the elites. This is symptomatic of how politics is moving. Many young people are no longer interested in the electoral process or in the activities of their representatives. They are passionate about a particular issue such as climate change, or the fate of a particular species, or sweatshop labour. Issues such as these do not translate into the kind of political engagement that is easily captured by traditional media focusing on the activities in the nation's capitals. 
Little wonder then that, as it often appears, young people seem 'apathetic' or 'switched off'. If what we mean by these terms is an interest in mainstream electoral politics then that may be true. But as my comments indicate, there is more to the story than this. Much more.

However we think about the health of representative politics it is difficult to avoid the conclusion that the crisis is permanent rather than temporary. But why is this? What are the drivers of the underlying change that we are witnessing in the advanced democracies?

This is a complex and highly contested question, and one that only elicits a lot of head scratching amongst interested commentators. But what I would add is the degree to which this collapse in the attractiveness and credibility of representative politics is not limited to official or mainstream political processes. It is something that is quite observable across a broad range of political phenomenon, whether it be the emergence of an anti-representational discourse in the Zapatista insurgency or the similarly non-representative Charter of the World Social Forum, perhaps the most discussed product of the last phase of revolt before this one - the anti-globalisation movement (Sen, 2004; Tormey, 2006).

Clearly there is something going on that takes us beyond disaffection with mainstream politics. There is a major shift or transformation underway in the nature of political subjectivity such that representation, the practice of being represented or representing others, has become something to be avoided, resisted, negated. When we think back to the vital role that representation has played in terms of the development of movements such as socialism and communism, and also the role it continues to play in many parts of the world where poverty is politically disabling, this is a remarkable phenomenon. It is also a highly complex one where caution is needed before proceeding. Nevertheless I want to offer a few observations about what I think this means and where it is heading for our purposes.

\section{WHAT'S THE MATTER WITH REPRESENTATIVE POLITICS?}

Representative politics is in historical terms the product of the early modern imagination (Manin, 1997; Brito Viera and Runciman, 2008). The first theorist to discuss representation as intrinsic to the legitimacy of the sovereign was Thomas Hobbes writing in the middle of the 17 th century. Representation as a political practice and the means by which societies 
came to democratise themselves is a phenomenon of the late 18th and early 19th centuries. It is associated with the emergence of collective identities and in particular class, nationality and ideology. Under each of these headings citizens were encouraged to see themselves as part of some larger aggregate identity that could be represented whether in the form of a political party, a nation-state or a political movement. The politics of the period resonated strongly with calls to these identities as the basis of mobilisation: «Power to the people!»; «Workers of the world unite!», «We hold these truths to be self-evident...»; «Man was born free, yet everywhere is in chains». We could go on.

The important dimension of representative politics was that ordinary people felt the need and desire to be represented. They identified with the signifiers and felt that they were included in the proclamations and discourse of those who would represent. What is becoming clearer is that this process of identity formation is becoming more difficult, less complete, more problematic. Globalisation promotes a different dynamic, one that is highly disruptive of the formation of collective or aggregate identities. To take class as one example, where under Fordist conditions it was clear who the workers were, what their shared interests are, and equally who the managers were and what their interests were, under post-Fordist conditions such distinctions of position, power and privilege become blurred. Earlier industrial processes based around factories, mines, and mass production are giving way to varieties of affective labour that complexifies class formation. The neat distinctions of class that are so clarifying in political terms have given way a dominant ideology that insists that we can advance through hard work, determination and 'positive thinking'. Class politics has been in decline and along with it the hopes of those who see politics in terms of the defence of the needs and interests of the poorest elements in society. One of the victims of the ebbing of representative politics has been social democratic parties whose rationale was to defend the working class from the more rapacious aspects of contemporary capitalism. And yet social democratic parties have suffered the same fate as all the rest: decline, exhaustion and slump.

It is not just class identity that has fragmented under the pressure of changes associated with globalisation, it is also national and ethnic identities. A key feature of globalisation is transnational migration caused by wars, climate change, economic opportunity, collapsing forms of governance, decolonisation, and so on. The accelerating movement of peoples, particularly towards the metropolitan spaces is deeply disruptive of the formation and 
maintenance of clear and distinct identities around which representation and representational politics rotates (Sassen, 2006). What seems more to be the case is that second and third generations develop novel and hybrid kinds of identity that induce a perception of 'newness' that is difficult to capture in representational terms. This doesn't prevent states from trying to bolster a sense of national identity or 'patriotism' in multicultural citizens. Many states spend huge sums of money trying to generate that sense of common identity they believe to be essential to maintain community and a sense of common purpose. With mixed results, it has to be said.

When combined with another facet of our contemporary world, communicative abundance, it is clear that subjects have access to such a plethora of kinds and forms of information that seeking to bring this multiplicity back into a unified political subject is becoming an ever more demanding exercise. The metropolitan space is characterised by a high degree of individualisation (or 'personalisation' as this phenomenon is also termed) in which subjects perceive themselves to be the authors of their own destiny as opposed to being tied to the collective fate of a particular identity or group. This, too, is part of the modern imaginary, and arguably serves the needs and purposes of capitalists better than it does their critics. As long as individuals are defined in terms of differentiation by consumer preferences, then of course it can be recuperated by capitalism in a way that is self promoting. If by 'individualisation' is meant choosing a pair of Nikes, as opposed to a pair of Adidas, then there is obviously no threat to the status quo. However, the story is more complicated than that. Individualisation can also inform and promote a kind of reflexivity towards received truths and inherited institutions and practices (Beck et al., 1994). It's partly for this reason that commentators such as Robert Putnam are so wary of the modernising tendencies that underpin the process of individualisation. He would prefer us to be tied into a pattern of activity and identity associated with our parents and grandparents, a kind of embedding in local community structures that can be trusted to produce docile and obedient subjects (Putnam, 1995).

Reflexive subjects on the other hand would seem to be far from docile or obedient. They are, on the contrary, questioning, critical, demanding of authority, politicians, states. Gone it seems is the aura of authority no matter where it is located - and not just in politics. The aura of doctors is challenged by access to mountains of information over the Internet against which to check their prognosis and prescriptions. The aura of university lecturers is challenged by students with access to the very same sources and materials as lecturers themselves. We live in a world where individuals in- 
creasingly feel themselves to be sources of authority on whatever it is they take an interest in. The Internet has provided an infinite amount of knowledge, encouraging the perception that the division of labour between those who 'know' and those who don't, those who lead and those who follow, is redundant (Shirkey, 2009). Professionals and those enjoying positional authority have seen their power base wither. The monopoly on knowledge, insight, wisdom - once taken for granted by intellectuals - is disappearing. Individualisation at this level represents a certain self empowerment, and one that makes us reluctant to cede voice, influence, power to others. Individualisation is corrosive of the very rationale that prompted support for political parties, trade unions and other bodies created to represent others: the need to empower someone else to pursue collectives needs and interests. That ideology or imaginary is rapidly dissolving in the acid bath of individualisation.

\section{THE POLITICS OF INDIVIDUALISATION}

It is a common assumption amongst sociologists interested in the impact of individualisation to draw pessimistic conclusions about the impact of these developments on politics. Individualisation at one level represents individualism, or the pursuit of my own needs and desires to the exclusion of consideration for others (Bauman, 2001). There is certainly an element of truth in the suggestion. However, concluding that individualisation necessarily results in such outcomes needs to be treated with caution. As is now well documented, individualisation can also be the basis for collective action, albeit of a novel kind. One of the most eye-catching developments in recent years has been the growth of ethical consumerism or ethical shopping (Micheletti, 2003).This is using the power of the consumer to generate better outcomes for otherwise exploited groups often located in the developing world or in the poorer parts of society. Through the use of boycotts or buy-cotts consumers, so it is held, can exercise a significant degree of influence over corporations, supermarkets and other actors in the marketplace.

This is a mild iteration of what is now termed 'swarm logic' or the power of 'the crowd' (Howe, 2008; Miller, 2010). Swarms and crowds obey a different logic to those engaged in representative politics where there is a natural distinction between those who represent, the active part, and those who are represented, who are the passive or pacified part. Individuals engaged in swarm politics are themselves actors. More than this they are not directed 
by someone, but rather part of an ecology that is itself without direction from above or anywhere else for that matter.

This sense of a collectivity that obeys its own logic is attractive to political theorists seeking a style or manner of acting 'beyond' or 'after' representation. To take an obvious example, Hardt and Negri evoke such a politics in their idea of the multitude as the subject of a contemporary radical praxis (Hardt and Negri, 2004). They look forward to the time when 'the multitude' is able to govern itself without the need for representatives or interlocutors. Their account is informed by a vision of biopolitical production that sets great store by the potentiality of technology to erase the need for intermediaries. It's a demand that is on the rise in the contemporary political context as activists latch onto the potentiality of P2P networking and other technologies that promote self-activity and direct participation (Toret, 2013).

It is difficult not to conclude that there is a certain romanticism at work in imagining that technology will enable the development of a kind of transparent self-governance of the kind promoted by Hardt and Negri. Crowd or swarm logic is best conceptualised in terms of the performance of relatively simple actions: the initiation of an occupation, a protest against a parliament, acts of self defence against police or military brutality and so on (Arquilla and Ronfeldt, 2000). They are thus best conceptualised in terms of an evanescent style of politics. Crowds and swarms are summoned quickly for a relatively simple or straightforward purpose, and disappear once that purpose has been fulfilled or the rationale completed. The more complex the terrain, the more complex the variables in terms of decision-making, the greater the need becomes for quasi-permanent institutionalisation, structures, accountability, constitutions. As we see in the unfolding occupations in Spain, the swarm like logic that initially brought people onto the streets quickly developed a different dynamic, that of the deliberative assembly (Castañeda, 2012). Once decisions had to be made, so differences of opinion and perspective required procedure, deliberative norms around participation, voting mechanisms and so forth. In short, swarm-like behaviour quickly developed into what we might term politics, or the management of dissensus.

Equally significant in terms of how these events and initiatives have unfolded is the resistance to generating representative structures and procedures. As we have already remarked, very few of the events and initiatives that we have been documenting gave rise to representatives or to representative bodies - even if one of their purposes is to call for greater repre- 
sentation, a second transition, a recall of Parliament. In this sense the individualised character of these revolts is clear to see. Over and again we notice the reluctance of participants in these events to nominate others to speak for them. We notice rather a clear preference for direct democratic and deliberative procedures that preserve the integrity of each singular voice within the initiative. We notice the hostility towards the development of bureaucracies, standing officers and officialdom, majoritarian voting practices and all the other paraphernalia associated with representative politics. These are eruptions of a highly individualised kind, but whose character is the generation of political procedures that seek to be participatory, consensual and deliberative - or genuinely collective. Of course not all of these initiatives lived up to these expectations. Perhaps none of them did or have done so to date. But the point is they often have a prefigurative aspect to them in the sense of embodying an ideal or vision of democracy sharply at odds with the practice of actually existing representative democracy. In other words many of these movements and revolts carried within them an immanent and sometimes quite explicit critique of representation and representative democracy whilst at the same time pointing towards other kinds of democracy felt to be more authentic or in the expression of the Spanish protesters 'real' - as in Real Democracia Ya.

So returning to the earlier problematic, I don't think that the emergence of an individualised politics necessarily equates to the kind of introspective, narcissistic or self-interested politics that is often assumed in the commentary. What it does equate to is the rejection of what for the past 200 years has been the standard form that politics has taken: a political party with a clear programme or manifesto seeking to represent the needs and interests of a particular group, class, nationality or ethnicity. What is becoming clear is that whatever future there is for the political party lies in it rejected the vertical logic formerly associated with political parties, which is to say a more or less sharply differentiated division of labour between party leaders and the rest. Political parties can and will survive, but only on the basis that they become flatter, more horizontal and better able to engage interested individuals as part of a collective and participatory ecology (Hughes, 2011; Gautney, 2012).

The emergence of Podemos and Syriza is of course an interesting test of the hypothesis: 'street' parties that are able to combine both a coherent 'vertical' or populist face to the electorate with a sense of engagement for activists who might otherwise be directing their energies to more avowedly horizontal or 'connective' initiatives. It's a difficult trick to pull off, though 
perhaps vital if the insurgent styles of anti-austerity, pro-democracy activisms on display are to leverage institutional and political change in the short and medium term. However, theirs is a very different mission and 'politics' to that of the traditional left parties they seem to be supplanting (PSOE, PSOK). Gone the accent on building membership, capacity, funding for the long slow deliberative assault on elections, the cronyism and careful manipulation of delegates at the party conference and so on. Replaced by a politics of excitement, immediacy, connectedness that speaks directly to the politics of the streets and squares from where many of their voluble supporters have come from.

There will be leftists out there who say that socialist and communist parties have more or less approximated this form since the early debates in the first working men's international. Yet the history of party politics offers mixed evidence. Examples of really inclusive political parties have been few and far between. But ICT is undeniably a game changer. It offers the prospect of much greater interactivity, transparency and participation that has hitherto been possible - for new and old parties. At the same time this high degree of porosity and transparency creates other kinds of issues for activists to overcome. In the past the success and failure of political parties has often traded on the credibility of those chosen to lead it. The successful parties of the past two centuries were led by charismatic or exemplary individuals able to mobilise ordinary people at election time as well as activists between elections. Will the new political parties, the new political organisations feel the need to invest in leader figures, in populist strategies and tactics? And if they do, will this alienate those whose political instincts lead them to reject representatives and represented politics? These are not just hypothetical questions. They get to the heart of the issues facing activists in Spain, Greece, Turkey and elsewhere where the initial energy of street politics has given rise to opportunities to advance in electoral terms as well as in terms of the swarm or crowd.

\section{WHERE IS THE MOVEMENT NOW?}

Before answering this question directly, it might be useful to rehearse the central components of the argument offered here. What I have been suggesting is that to understand the current phase of revolt and rebellion requires us to step back and take a larger view of what is happening in the political field. What I noted was the similarity between the various revolts around the 
world in terms of a rejection of the traditional structures associated with representation and representational politics in favour of immediate and direct action - greatly facilitated by ICT. We then went on to note that this is consonant with the wider crisis of representation playing out to greater or lesser degree across representative democracies. Whilst many commentators insist that this crisis is located in short-term or contingent factors such as the politics of austerity or recession, in my view it is consonant with larger changes in the nature of modernity. This is the modernity of nation states, of discrete territorial entities enjoying sovereignty over their affairs, and presiding over a relatively homogenous ethnic or national group. Globalisation is highly disruptive of this pattern of political affinity and identity. It is also highly disruptive of sovereignty and territoriality, which in turn have been the basis of contemporary governance. More broadly, modernity also equates to individualisation, or the adoption of modes and patterns of behaviour that escape categorisation in terms of collective identities. Individualisation is thus corrosive of representation and representative politics.

I would argue that the revolts and rebellions that we see around Europe and indeed the world have in common their rejection of the logic of representative politics and representation more generally. This often means that they are seen as anti-political gestures, a rejection of politics and democracy. I think the opposite is true. What unites many of these initiatives is the realisation that representation is being used as a cover for the domestication and emasculation of politics for the benefit of the few, or the $1 \%$. Where once there seemed some credibility to the idea that politicians spoke for us, and on our behalf, that credibility has increasingly waned if it has not disappeared altogether, hence the resonant power of contemporary slogans such as «We are the 99\%» and «Real Democracia Ya» - in their own quintessential representative slogans - but at another angle anti-representative, particularly when it comes to thinking about what representative politics has become: the politics of the $1 \%$. The figure of the politician has instead become a proxy for a kind of zombie-fication of politics, a politics that seems to be 'full of life', but is instead better understood as a parasitic body sucking the life and energy out of communities (Giroux, 2011). But rather than turn to other kinds of politician, to revolutionary leaders or heroic figures, what is noteworthy in the current conjuncture is the manner by which these initiatives have set their face against renewing the parties, trade unions and traditional organisations did the job of representing us. It is as if the tenor of political action has undergone a paradigm shift away from the preoccupation with generating new representative bodies, figures, claims towards a «connective 
politics», a politics of networks, swarms, collectives, occupations, prefigurations (Bennett and Segerberg, 2012). Politics is undergoing a Gestalt shift. This still leaves the question of where all this is going.

As is clear then, in looking at present revolts, rebellions, protests we are not describing a movement of a traditional kind. Far from it, we are describing a rhizomatic movement against traditional 'politics' including the traditional oppositional politics (Deleuze and Guattari 1988). What we are seeing is the rejection of the preoccupation with programmes, manifestoes and such like towards what we might call a resonant form of politics where the object is less the promotion of a singular ideal about how we should live so much as the recuperation of political agency and political space. In doing so these movements and revolts remind us how far contemporary political practices have moved from the ideal of democracy as the affair of 'anyone and everyone'. It reminds us that representative democracy was born not as a mechanism for permitting us to govern ourselves, but as J.S. Mill reminds us, as a means of preventing us from being 'misgoverned' (Mill, 1972). Mill's quote reminds us that the origins of representative democracy bear their trace in the desire of those already in power to prevent 'tyranny of the majority' or what might ordinarily be regarded as democracy (Manin, 1997). From this point of view democracy is not a first order quality of contemporary political systems, but a second order means for ensuring that property and privilege remain intact. Democracy has long been regarded by liberal elites as a provisional and contingent virtue, and one that could only be justified insofar as it permitted accumulation, dispossession and acquisition of further wealth. Quite simply, representative democracy has been the handmaiden for capitalist globalisation.

Just as the dream of constant expansion crashed and burned in financial crisis, so the dream of democracy as a Schumpetarian 'rotation of elites' has crashed and burned in the profligacy, corruption and heartless self-serving of today's politicians. Many of today's revolts and rebellions, though born of economic discontent, nevertheless carry an important political message. This is that the era of the politician as privileged actor-expert working on our behalf is over.The era of the recuperation of political power and agency by individuals acting together collectively is just beginning. So the irony is that just at the moment when media dominated elites want to tell us that these protests and revolts are a threat to democracy as 'anti-politics', the reality would seem to be the reverse: they are movements that articulate in direct, and increasingly visceral terms, the desire of many ordinary people to 
exercise greater control over the world in which they live and not to be subject to a far-removed political and economic class.

So perhaps democracy as a concept is coming full circle. As Ranciere reminds us, democracy used to mean a raucous, noisy resonant politics that engaged everyone (Rancière, 2006). So determined were the Greeks to operationalise this idea of rule by anyone and everyone that they insisted that democratic office holding be allocated on the basis of $l o t$, thereby undercutting the possibility for elites to exercise domination over the demos. But it was Plato and those who, as Ranciere puts it, 'hate' democracy who won the day, devising a mechanism whereby our interests and needs could act as proxies for direct participation and deliberation in common affairs. In challenging rejecting representative styles and modes of politics, the politics of the 'politicians', today's revolts are not just a negation - of governance, representatives, organised politics - they evince a democratic sensibility: the demand of ordinary people to count, to be heard, to participate. Today's revolts are not a challenge to democracy - they are democracy. Its by no means ironic that the epicentre for this new style of politics: a raucous, 'unruly' politics in which 'the demos' appears as both subject and object of politics seems to find its fullest voice in Greece - home of the democracy of «anyone and everyone».

\section{REFERENCES}

Alonso, S. (2014): «Votas pero no eliges: la democracia y la crisis de la deuda soberana en la eurozona». Recerca. Revista de Pensament i Anàlisi, 15, pp. $21-53$.

Anduiza, E., Cristancho, C. and Sabucedo, J. M. (2014): «Mobilization through

Online Social Networks:The Political Protest of the Indignados in Spain», Information, Communication \& Society, 17(6), pp. 750-64.

Arquilla, J. and D. Ronfeldt (2000): «Swarming and the Future of Conflict»,

RAND Corporation, Available at: http://www.rand.org/publications/DB/

DB311/. (Retrieved August 2 2004).

Bauman, Z. (2001): The Individualized Society, Cambridge, Polity Press,.

BeCK, U., A. GIDDENs and S. LASH (1994): Reflexive Modernization : Politics,

Tradition and Aesthetics in the Modern Social Order, Cambridge, Polity.

Bennett, W. L. and A. Segerberg (2012): «The Logic of Connective Action», Information, Communication E Society, 15(5), pp. 739-768. 
Brito Viera, M. and D. Runciman (2008): Representation, Cambridge, Polity. Castañeda, E. (2012): "The Indignados of Spain: A Precedent to Occupy Wall Street», Social Movement Studies, 11(3-4), pp. 309-319.

Castells, M. (2012): Networks of Outrage and Hope: Social Movements in the Internet Age, Cambridge, Polity Press.

Christensen, H. (2011): «Political Activities on the Internet: Slacktivism or Political Participation by Other Means?», First Monday 16. Available at: http://firstmonday.org/article/view/3336/2767 (Retrieved May 2014).

Datton, R. J. (2004): Democratic Challenges, Democratic Choices: The Erosion of Political Support in Advanced Industrial Democracies, Oxford, Oxford University Press.

Deleuze, G. and F. Guattari (1988): A Thousand Plateaus: Capitalism and Schizopbrenia, London, Athlone Press.

Feenstra, R. (2015): «Activist and Citizen Political Repertoire in Spain:A Reflection Based on Civil Society Theory and Different Logics of Political Participation»,Journal of Civil Society (Online First).

FEenstra, R. and KeANe, J. (2014): «Politics in Spain:A case of monitory democracy», VOLUNTAS. International Journal of Voluntary and Nonprofit Organizations, 25, pp. 1262-1280.

Fuinders, M. (2012): Defending Politics: Why Democracy Matters in the Twenty-First Century, Oxford, Oxford University Press.

Gauntney, H. (2012): Protest and Organization in the Alternative Globalization Era: NGOs, Social Movements, and Political Parties, London, Palgrave Macmillan.

Giroux, H. A. (2011): Zombie Politics and Culture in the Age of Casino Capitalism, New York, Peter Lang.

Goot, M. (2002): «Distrustful, Disenchanted and Disengaged? Polled Opinion on Politics, Politicians and the Parties: An Historical Perspective», Parliament and Public Opinion, Papers on Parliament 38. Available at: http:// www.aph.gov.au/senate/ / /link.aspx?_id=AC6C7A66BBC149AC9C675 C57939B5591\&_z=z (Retrieved January 2014).

Hardt, M. and A. Negri (2004): Multitude:War and Democracy in the Age of Empire, New York, Penguin.

HaY, C. (2007): Why We Hate Politics, Cambridge, Polity.

Hill, S. (2013): Digital Revolutions: Activism in the Internet Age, London, New Internationalist.

Holloway, J. (2002): Change the World without Taking Power, London, Pluto Press. 
Howe, J. (2008): Crowdsourcing: How the Power of the Crowd Is Driving the Future of Business, New York, Random House.

Hughes, N. (2011): «Young People Took to the Streets and All of a Sudden All of the Political Parties Got Old': The 15M Movement in Spain», Social Movement Studies, 10(4), pp. 407-413.

MaIR, P. and I. VAN BIEZEN (2001): «Party Membership in Twenty European Democracies, 1980-2000», Party Politics, 7(1), pp. 5-21.

Manin, B.. (1997): The Principles of Representative Government, Cambridge, Cambridge University Press.

Marcos, Subcomandante.(2001): Our Word Is Our Weapon: Selected Writings, London, Sepent's Tail.

Markus,A. (2013): «Mapping Social Cohesion», Melbourne: Monash University. http://www.scanlonfoundation.org.au/docs/2013_SocC_report_final. pdf.

Mason, P. (2013): Why It's Still Kicking Off Everywhere: The New Global Revolutions, London, Verso.

Micheletti, M. (2003): Political Virtue and Shopping: Individuals, Consumerism and Collective Action, New York, Palgrave.

Mill, J. S. (1972): «Considerations on Representative Government», Three Essays.J. S. Mill, Oxford, Oxford University Press.

Miller, P. (2010): The Smart Swarm: How Understanding Flocks, Schools, and Colonies Can Make Us Better at Communicating, Decision Making, and Getting Things Done, New York, Avery Publishing Group, Inc.

Morozov, E. (2012): The Net Delusion: The Dark Side of Internet Freedom, London, Penguin.

Postill, J. (2013): «Democracy in an Age of Viral Reality:A Media Epidemiography of Spain's Indignados Movement», Etbnograpby. 15(1), pp. 50-68.

Putnam, R. D. (1995): «Bowling Alone: America's Declining Social Capital», Journal of democracy, 6(1), pp. 65-78.

RANCIERE, J. (2006): Hatred of Democracy, London, Verso.

SAssen, S. (2006): Territory, Autbority, Rights: From Medieval to Global Assemblages, Princeton, Princeton University Press.

SEN, J. (Ed.) (2004): World Social Forum: Challenging Empires. New Delhi: Viveka.

SHIRkey, C. (2009): Here Comes Everybody: The Power of Organizing without Organizations, New York, Penguin.

Toret, J. (Ed.) (2013): Tecnopolítica: La Potencia De Las Multitudes Conectadas. El Sistema Red 15m, Un Nuevo Paradigma De La Política, Barcelona, UOC. 
Tormey, S. (2015): The end of Representative Politics, Cambridge, Polity.

- (2013): Anti-Capitalism:A Beginner's Guide, Oxford, Oneworld.

-(2006): "Not in My Name': Deleuze, Zapatismo and the Critique of Representation", Parliamentary Affairs, 59(1), pp. 138-154.

Van Biezen, I., P. Mair, and T. PoguntKe (2012): «Going, Going,... Gone? The Decline of Party Membership in Contemporary Europe», European Journal of Political Research, 51(1), pp. 24-56.

Vromen, A. (2003): "'People Try to Put Us Down...': Participatory Citizenship Of'generation X» Australian Journal of Political Science, 38(1), pp. 79-99. 